\title{
Regional Governance Based on the Value of Local Wisdom (Study of Ternate Empire)
}

\author{
Nam Rumkel ${ }^{1}$, Tri Syafari ${ }^{2}$, Yahya Yunus ${ }^{3}$ \\ \{namrumkel@yahoo.com ${ }^{1}$, trisyafari.unkhair@gmail.com ${ }^{2}, \underline{\text { humano@ unkhair.ac.id }}{ }^{3}$ \} \\ Faculty of Law, Khairun University of Ternate, Indonesia ${ }^{1,2,3}$
}

\begin{abstract}
In Indonesia many areas have their own customary law, of course the customary law is derived from the oral tradition of the ancestors. Starting from Aceh to the Papua region has its own oral tradition story. But unfortunately, in the era of globalization and sophistication of science today make oral traditions in areas of Indonesia increasingly abandoned, especially the young generation as a successor to the oral tradition of the ancestors in the future. Customary law is a term given by law science circles in the past to the group, the guidelines and the reality that regulate and discipline the life of the people of Indonesia. Scientists at the time saw that the people of Indonesia, who live in remote areas live in order and they live orderly by referring to the rules they make themselves. Similar to in other parts of Indonesia, the triumph of the four empire of the earth Moloku Kie Raha (North Maluku) slowly began to be forgotten. In fact, Ternate Empire in the reign of Sultan Babullah dubbed the Ruler of 72 nations. The honor was obtained after that time, the Ternate Empire has a very large conquered area up in Mindanao, the Philippines to Sabah, Sulu, even the island of Timor. Based on the exposure, this paper will discuss about the values of local wisdom in Ternate that still exist and local governance that accommodate the values of local wisdom.
\end{abstract}

Keywords: Customary Law, Ternate Empire, The Value Of Local Wisdom Local Governance

\section{Introduction}

Humans are created on earth with diversity which is a gift from God Almighty. Nations and tribes are created by Him which is different between one nation and another, as well as one tribe and another tribe which has different characteristics. Even with the meaning of diversity shows that Allah created human beings with the best of creatures with the concept of diversity that has been arranged by him.

The concept of Bhineka Tunggal Ika which means different but one. Indonesia in addition to a variety of tribes, also has a very wide area so that government is formed in the regions in the form of a unitary state with the concept of regional autonomy to the greatest possible extent. in one container whose name is the Unitary State of the Republic of Indonesia but adheres to the meaning of diversity between various existing elements, it requires a basic framework that can unite these various elements within a framework of the State.

The regional government as mandated in the second amendment to the 1945 Constitution of the Republic of Indonesia (hereinafter abbreviated as 1945 Constitution of the Republic of Indonesia) in Chapter VI Article 18, Article 18A and Article 18B, that the provincial, district, and municipal governments regulate and manage themselves government affairs according to 
the principle of autonomy and co-administration. So that the implementation of regional government goes as expected. So, the government implements government with the concept of regional autonomy. The implementation of regional autonomy should be directed to accelerate the realization of public welfare through improving services, empowerment, and community participation, as well as increasing regional competitiveness by paying attention to the principles of democracy, equity, justice, and peculiarities of an area in the system of the Unitary State of the Republic of Indonesia (hereinafter abbreviated NKRI). ${ }^{1}$

The implementation of regional autonomy with the concept of decentralization is a symbol of trust (trust) from the central government to the regional government, this will in itself restore the self-esteem of the government and regional community. If in a centralistic system, they cannot do much in overcoming various problems, in this autonomous system they are challenged to creatively find solutions to various problems faced. This is important because the state recognizes and respects the unity of indigenous peoples and their traditional rights as long as they are alive and in accordance with the development of society and the principles of the Republic of Indonesia Unitary State, which is regulated in law. Thus the state opens the opportunity for the regions to develop their regions by their own initiative according to the specificities of the region as long as they are not in conflict with the principles of the Republic of Indonesia. The state promotes Indonesia's national culture in the midst of world civilization by ensuring the freedom of the people in maintaining and developing cultural values.

From year to year since the reformation began, the law on regional government continued to change, starting with Law of the Republic of Indonesia Number 22 Year 1999 being replaced by Law of the Republic of Indonesia Number 32 Year 2004 until it was replaced by Law Number 23 of 2014 concerning Regional Government. In the general explanation Law of the Republic of Indonesia Number 23 Year 2014 regulates the existence of local wisdom that: ${ }^{2}$ From the legal aspect, local wisdom is well accommodated in the 1945 Constitution of the Republic of Indonesia and the Law. In addition, local wisdom is also accommodated in Law of the Republic of Indonesia Number 32 Year 2009 on Environmental Protection and Management in Chapter IX Article 63 paragraph (1), in letter (t) the Article stipulates that: ${ }^{3}$

"Establish policies regarding the procedures for recognizing the existence of indigenous peoples, local wisdom, and indigenous peoples' rights related to environmental protection and management. Local wisdom is ideas or values, local views that are wise, full wisdom, good value embedded and followed by members of the community. Local wisdom is a source of knowledge that is dynamically developed and transmitted by certain populations that are integrated with their understanding of the surrounding nature and culture". 4

Based on the results of research conducted almost the same as what was carried out by the Partnership Institution (Lembaga Kemitraan) conducted on good governance in several regions in Indonesia, the results show that there are still many regions that have not carried out implementation properly based on indicators of general principles of state administration, so

\footnotetext{
${ }^{1}$ Consideration of Law of the Republic of Indonesia Number 22 Year 2014 on Regional Government, State Gazette of the Republic of Indonesia Year 2014 Number 244.

${ }^{2}$ General Explanation of Law of the Republic of Indonesia Number 23 Year 2014 concerning Regional Government, State Gazette of the Republic of Indonesia in 2014 Number 244.

${ }^{3}$ Article 63 paragraph (1) of Law of the Republic of Indonesia Number 32 Year 2009 on Environmental Protection and Management, State Gazette of the Republic of Indonesia Year 2009 Number 140.

${ }^{4}$ Aminuddin, 2013, Menjaga Linkungan Dengan Kearifan lokal, Titian Ilmu, Jakarta, p. 14
} 
impact on the poor service and the welfare gap in the people in the area who have problems in terms of governance that is not good. The results of this study indicate that the Regional Government of North Maluku Province ranks the 3rd (three) worst in terms of governance in the Indonesia Governance Index. ${ }^{5}$

Therefore, it is the most determined in the implementation of state government and national development to achieve a just, prosperous and equitable society based on Pancasila and the 1945 Constitution, Article 1 of the 1945 Constitution stipulates that the State of Indonesia is a unitary state in the form of a Republic. Furthermore, in Article 18 of the 1945 Constitution along with its explanation states that the Indonesian region is divided into autonomous or administrative areas.

\section{Research Method}

This type of research is normative legal research ${ }^{6}$ and empirical legal research using legislation approach, conceptual approach, and case approach. ${ }^{7}$ There are two types of data in this study, namely (1) primary data, i.e. data derived from the results of interviews and observations, (2) secondary data i.e. data obtained from library research and documents. The data collected through the stages of editing, then coding and analyzed using descriptivequalitative techniques.

\section{Results and Discussion}

\subsection{Regional Governance Concept Based on North Maluku Local Wisdom.}

North Maluku Province is an area that cannot be separated from the history of this nation, because there are 4 (four) Kingdoms ${ }^{8}$ which at the time of the archipelago maintained its territory from colonialism which came from the Portuguese, Dutch and Japanese who targeted the region and natural wealth such as spices owned, but thanks to the persistence and resilience of the Sultan in the 4 (four) Kingdoms, the North Maluku region still existed and then voluntarily united to build the Unitary State of the Republic of Indonesia.

Departing from the historical concept, the concept of regional government is actually the meaning of the existence of regional autonomy which gives meaning to the implementation of regional governance. ${ }^{9}$ Therefore, in the implementation of regional government, one of the most important principles by emphasizing the principle of regional autonomy by using the principle of autonomy as broadly as possible means that the region is given the authority to

5 An annual governance assessment by the Partnership Institution, accessed at "http://www.kemitraan.or.id/govindex/ dated October 20, 2015

${ }^{6}$ Soerjono Soekanto and Sri Mamudji, Penelitian Hukum Normatif, Jakarta: Rajawali Pers, 2011 , p. 14

${ }^{7}$ Peter Mahmud Marzuki, Penelitian Hukum, Jakarta: Kencana Prenada Media Group, 2010, p. 96

${ }^{8}$ The kingdom included the Kingdom of Ternate, the Kingdom of Tidore, the Kingdom of Bacan, and the Kingdom of Jailolo. Although in its history there are the oldest kingdoms in North Maluku, the kingdom of Loloda, but those that still exist today are the remaining four kingdoms, in M. Adnan Amal, 2010, Kepulauan Remah-Rempah, Perjalanan Sejarah Maluku Utara 1250-1950, KPG, Jakarta, p. 25

${ }^{9}$ Siswanto Sunarno, Hukum Pemerintahan daerah di Indonesia, Jakarta: Sinar Grafika 2008, p. 8 
make regional policies to provide services to increase the role and initiative and empowerment of the community aimed at improving people's welfare. The concept actually shows that the design of regional government with the concept of governance provides reinforcement so that in the governance process goes according to what is the basic principle in the regional government, by offering a model for the implementation of regional autonomy which also contains the principle of real autonomy and responsibility.

The principle of real autonomy emphasizes that to deal with regional government affairs is carried out based on duties, authorities and obligations which in fact exist and have the potential to grow live and develop in accordance with regional potential and peculiarities. Thus, of course, the content and type of autonomy for each region are not always the same as other regions. Whereas in the sense of responsible autonomy it is seen as autonomy which in its implementation must be truly in line with the objectives and purpose of granting autonomy, which is basically to empower the region including improving people's welfare which is a major part of national objectives.

The meaning of local governance is not only seen as an application of the concept of regional autonomy but can also be interpreted as a regional authority that has a government to regulate and manage the interests of local communities according to their own initiative based on the aspirations of the community in accordance with the implementation of legislation. ${ }^{10}$ Local governments as part of the central government with various obligations, with various formats of governance are highly expected to prosper the people with various policies carried out with the concept of meaning management. The concept of improving community welfare is a major step in determining the policy strategy in regional development, the essence of the meaning of welfare is to involve the lives of many people which includes various dimensions: ${ }^{11}$ In the political field, it is directed to a system of political fostering in a dynamic, democratic area, more specifically is the development of people's political life so that they can participate in every development process in the region. In the economic field, it is directed to provide the widest possible opportunity in economic and trade activities.

In the field of social, education, health, directed to improving the quality of social life, improving the quality of education, the quality of health so as to increase the quality of population growth both from the outer and inner aspects. In the field of culture, directed to improving the quality of regional culture while preserving the noble culture of the nation with national and international dimensions so that it can strengthen the spirit of nationalism in the frame of the Republic of Indonesia. In addition, the preservation of regional culture can increase regional tourism activities that can increase foreign exchange and increase local income.

In the field of religion, directed to improving the quality of religious life so as to guarantee the freedom of its adherents to carry out worship in accordance with their respective religious beliefs. The harmony of religious life is always fostered to increase national unity in order to avoid social conflicts, as well as conflicts between religious adherents. In the field of law and security, directed to improve the quality of obedience and compliance with national law and local customary law so as to guarantee order, and to create a sense of security to support public welfare.

In accordance with Article 18 of the 1945 Constitution of the Republic of Indonesia, as a juridical consequence of the holding of regional government (regional division) in Indonesia

10 Dadang Solihin, Kamus Istilah Otonomi Daerah, Jakarta: Lembaga Pemberdayaan Ekonomi kerakyatan, 2001, p. 67

${ }^{11}$ Ibid, p. 10 
on the basis of decentralization is the birth of an autonomous region that has regional autonomy in organizing self-government affairs. In accordance with the mandate of the constitution, the regional government carries out governmental affairs that are its authority except for government affairs referred to in Law of the Republic of Indonesia Number 32 Year 2004 Article 10 paragraph 3 covering: ${ }^{12}$ (a) Foreign policy, (b) Defense, (c) Security, (d) Judicial, (e) National Monetary and Fiscal, and (f) Religion.

Although the pattern of division of authority in the administration of central and regional government affairs is clearly regulated in various regulations, especially in Law Number 23 of 2014 concerning Regional Government. The end of this regulation actually shows the delegation of authority to the regions to regulate their domestic affairs in order to improve public services. which in turn has a shift in prosperity from the center to the regions. So, the core of the implementation of regional autonomy with the concept of governance by providing the widest possible space for local governments (discretionary power) to organize their own government on the basis of initiative, creativity and active participation of the community in order to develop and fight for their respective regions. ${ }^{13}$

According to Amrah Muslimin, within the framework of administering government in a country, the government in a broad sense holds on to two kinds of principles, namely the principle of expertise and regional principles. In the regional principle, there are two types of governance principles, namely deconcentration and decentralization. ${ }^{14}$ Therefore in the context of regional government, the concept of autonomy is an essential part of decentralized government, in other words regional decentralized government cannot be imagined the running of regional government without the essence of regional autonomy. ${ }^{15}$

Regional autonomy is the authority of the government that is submitted to autonomous regions as a form of decentralization in the scope of a unitary state. Article 1 paragraph (1) of the 1945 Constitution of the Republic of Indonesia states that the State of Indonesia is a Unitary State in the form of a Republic. The implementation of the decentralization principle is in the context of realizing the authority of regional autonomy, so that it cannot escape the Unitary State of the Republic of Indonesia (Article 18 of the 1945 Constitution of the Republic of Indonesia). This provision is the basis for territorial or territorial decentralization. ${ }^{16}$ According to Bagir Manan, Article 18 of the 1945 Constitution of the Republic of Indonesia only regulates territorial decentralization, which is interpreted in a narrow sense, with the notion of territorial decentralization is nothing but political decentralization. ${ }^{17}$ The reason for this lies in the existence of regional factors. According to Bhenyamin Hoessein, ${ }^{18}$ in essence decentralization is the autonomization of a society that is in a certain territory. A society that was originally not autonomous through decentralization became an autonomous status by incarnating it as an autonomous region that has an independent regional government.

The authority to regulate and manage is the substance of an autonomous region conceptually organized by the regional government. Based on the above description, the

\footnotetext{
${ }^{12}$ Law of the Republic of Indonesia Number 32 Year 2004 on Regional Government, Jakarta: Indonesia Legal Centre Publishing, 2008, p. 8

${ }^{13}$ M. Ryaas Rasyid, Otonomi Atau federalisme, Jakarta: Pustaka Sinar Harapan, 2000, p. 4

${ }^{14}$ Amrah Muslimin, Aspek-aspek Hukum Otonomi Daerah, Bandung: Alumni, 1978, p. 14

${ }^{15}$ M. Laica Marzuki, Makalah, Otonomi Daerah dalam Perspektif Indonesia Baru, Ujung Pandang: 29 September 1999, p. 1

${ }^{16}$ R. Wiyono, Garis Besar Pembahasan dan Komentar UUD 1945, Bandung: Alumni, 1982, p. 125

${ }^{17}$ Amran Muslimin, Op.Cit, p. 15

18 Benyamin Hoessin, Kebijakan Desentralisasi, Jurnal Administrasi Negara, Vol. I, No. 02, March 2002, p. 3
} 
existence of regional autonomy given to the regions in the form of freedom and independence to govern and manage their own government is a manifestation of the demands for efficiency and effectiveness of public services. to the community in order to realize the welfare of the community. A good indicator of autonomy is autonomy that gives full freedom to each component to do anything as long as it does not conflict with the order's identity. ${ }^{19}$ In this context, local governance based on the values of local wisdom can be interpreted as the most important part of regional development with various concepts that want to be realized in local government.

Historically North Maluku, or more familiarly known as Jazira Moloku Kie Raha, one of the provinces in the eastern part of Indonesia, which had four sultanates and until now these sultanates still existed such as the Ternate Sultanate, the Tidore Sultanate, the Bacan Sultanate, the Jailolo Sultanate. If you can interpret the various values contained in it from the various sultanates, which can be interpreted as an effort to strengthen local government, it actually stores a variety of cultural diversity that not only becomes the identity of the local people of North Maluku but also national and international identity by interpreting the meaning of Moluku Kie Raha with local wisdom, ${ }^{20}$ Adat Se Atorang which means customs and rules, Jago loa Se Banari or honest and fair and Ceng se Cange or Popular and Humble. The local wisdom has a foundation with what is called a philosophical aspect called Philosophy: "Jo Se Ngofa Ngare", which means: "You" (the ruler) and "I" (the people), while in the sociological aspect called Balo Kesu Se kano-kano and the normative aspects that exist. These meanings provide important lessons for the people who are in the area to live life with values that lead to wisdom and wisdom in the procession of life. The value of unity, courtesy, ethics and procedures for social interaction, is taught accordingly, and is expected to be able to be realized in a social life. The historical value being taught becomes a great reflection, for every North Maluku community, which can later be learned and expected to be used in the procession of life.

Basically, the cultural values in Moloku Kie Raha are the same, but still in accordance with the structure of the community and their respective customary institutions. Ternate Sultanate is known as Coou value, which can be interpreted as full loyalty to the Sultanate without salary or expectation of getting rewarded. Whereas in Tidore it is known as Bari fola which means the value of mutual assistance to help one another without expecting any reward. For Bacan and Jailolo basically also have the same values.

The implementation of regional government based on the values of local wisdom is actually a reflection of a regional regulation that has been made by the executive and legislative in the area. Based on the provisions of Article $22 \mathrm{~A}$ above, Law of the Republic of Indonesia Number 10 Year 2004 on the Establishment of Legislation (State Gazette of the Republic of Indonesia No. 53 of 2004, Additional State Gazette of the Republic of Indonesia No. 4389) which is the elaboration of Article 6 of the Decree of the People's Consultative Assembly of the Republic of Indonesia Number III/MPR/ 2000 concerning Legal Sources and Order of Legislation. In the provisions of Article 7 of the Law of the Republic of Indonesia Number 10 Year 2004 is regulated in the hierarchy of laws and regulations consisting of (1) the 1945 Constitution of the Republic of Indonesia, (2) Law/Government Regulation in Lieu of Law, (3) Government Regulation, (4) Presidential Regulation, (5) Regional Regulations

${ }^{19}$ A. Mappadjantji Amien, Kemandirian Lokal-Konsepsi Pembangunan, Organisasi, dan Pendidikan dari Perspektif Sains Baru, Jakarta: PT Gramedia Pustaka Utama, 2005, p. 190

${ }^{20}$ Rahmatullah H. Sahil, Relevansi Kearifan Lokal Provinsi Maluku Utara dalam Penyelenggaraan Pemerintahan Daerah, Universitas Hasanuddin (Thesis for Master Degree), 2015, p. 66 
(Provincial Regulations, Regency/City Regulations, Village Regulations/Regulations that are equivalent). If we pay close attention to this law, especially in the provisions of Article 7, it is clear that Law of the Republic of Indonesia Number 10 Year 2004 explicitly places Regional Regulation (Perda) as part of the legislation.

\subsection{Ternate Local Wisdom Values in the Regional Governance of Ternate.}

Various values possessed by a group or community in the life of the nation and state are an integral part of the social life of society which can be interpreted as the philosophy of life. In such contexts, these values must be implemented in various aspects of social life. not only limited to a dimension. Confirmation of this matter is important because local wisdom is interpreted as a philosophy that lives in the hearts of the community, in the form of wisdom for life, way of life, traditional rites and the like. ${ }^{21}$

The meaning of life philosophy can at least show that local aphorism is a collection of knowledge created and believed by a group of people from generation to generation who live together and harmonize with nature. In this context, the state in this case the regional government must conduct various studies by mapping various values of local wisdom that are still alive and developing in accordance with the times, especially in Ternate, so that it can synergize with various policies made by the city government the expectation becomes important so that in realizing good governance in the region is not only seen from one dimension but other dimensions as well.

Such thing at least shows that the synergy between local government and various societies has a strong correlation because the integration between various values of local wisdom can be practiced in both formal and informal contexts in local government management. Local wisdom always develops through oral traditions of speech or through informal education and the like and always get additional from new experiences, but this knowledge can also be lost or reduced. Such a concept actually gives hope that in carrying out various interests of the community, the presence of local government is always needed in various aspects, because the values of local wisdom in Ternate always synergize with the central and regional governments, because it has several values such as (1) as a genuine knowledge of a society that comes from the noble values of cultural traditions to regulate the order of community life, (2) Able to withstand external cultures, (3) have the ability to accommodate elements of external culture. (4) has the ability to integrate elements of external culture into indigenous culture, (5) has the ability to control, and is able to provide clear direction and goals by paying attention to various things that can be generated from these various interactions.

The Ternate Emperor, as well as other sultanates/emperors in North Maluku, has various values of local wisdom which are manifested in the management of good governance. Of course, it must be seen as the most important part in the linking of regional government based on the Law of the Republic of Indonesia Number 23 Year 2014 in Article 1 paragraph 3 asserts that the Regional Government is the regional head as an element of the regional administration that leads the implementation of government affairs which is the authority of the autonomous regional affairs ${ }^{22}$.

${ }^{21}$ Armada Riyatno, et.al., Kearifan Lokal-Pancasila Butir-Butir Filsafat Keindonesian, Yogyakarta: PT Kanisius, 2015, p. 28

22 Article 1 paragraph (3) Law of the Republic of Indonesia Number 32 Year 2004 on Regional Government, Jakarta: Indonesia Legal Centre Publishing, 2008, p. 3 
The city of Ternate in which there is a Sultanate ${ }^{23}$ the Ternate Sultanate, ${ }^{24}$ which until now still exists, has the principles and philosophy of the administration of an inherent constitution being a value of the philosophy of the administration of the Sultanate government in carrying out its government based on law that has been compiled together according to the existing tribal unit into the Ternate Sultanate state philosophy known as the six basic precepts (Kie se gam magogugu matiti rara) ${ }^{25}$ related to social relations with its people. But in reality on the ground, the principles which are local wisdom have not been accommodated in the practice of regional governance in the concept of regional autonomy that customary law and local wisdom can be offered as an alternative solution in anticipating and overcoming all forms of inequality in governance in North Maluku Province, both as an ethical basis, in the form of Regional Regulations (Perda) or other policies in achieving good governance.

Good governance, is a concept in government management that has been popular since the nineties as if it were a new formula for therapy towards the mechanism of governance of a country to run democratically. Indeed, the principle or principles have long been the joints of government in a democratic country, as in the State of Indonesia the principles or principles have long existed, especially the values and customs of the culture of society as social capital and in line with the principle of participation, transparency and accountability, as well as opening space for community involvement. But these principles or principles as laws that live in society are simply ignored so that they are not used as a reference in public services. ${ }^{26}$

The principles that live in society are basically tested, this can be proven by being there, living, and still surviving the value of local wisdom up to now in local communities and made as a guide to living in relationships between fellow human beings and between leaders and their people. Regional development as an integral part of national development is carried out based on the principles of good governance. Thus the regulation of national resources, the hope to be able to provide opportunities for increasing democracy and regional performance to improve the welfare of society towards civil society that is free from various bad habits such as corruption, collusion and nepotism can be avoided at least such practices can be controlled by all elements. Since the Indonesian government from time to time such problems still color the administration.

Strengthening the governance of Ternate should be able to adopt what is called Bobato Dunia and Bobato Akhirat in the Ternate Sultanate. ${ }^{27}$ Both of these philosophies contain the meaning of the division of power, which regulates the problems of government or the world, and regulates the religious problems of Bobato Akhirat. Both of these concepts can actually provide a clear color in the management of local government in the City of Ternate, so the synergy between the values of the Ternate Sultanate becomes a necessity. Thus, the two structures by prioritizing the concepts of the government elite and diversity elite in the Ternate

${ }^{23}$ In using the name of the Sultanate in this proposal the author likens the same meaning to the Kingdom, but in North Maluku it is more appropriate to use the Sultanate because it is led by the Sultan (Kolano) who has Islamic nuances.

${ }^{24}$ The Ternate Sultanate was founded in 1257 marked by the coronation of Manshur Malamo as the first Sultan (in the ternate sultanate called Kolano) in M. Adnan Amal, Op.Cit., p. 55

${ }^{25}$ Abdul Hamid Hasan, Aroma Sejarah dan Budaya Ternate, Jakarta: Antara Pustaka Utama, 2001, p. 154

${ }^{26}$ Syamsul Bachrie, Merekonstruksi Paradikma Membangun Supermasi Hukum yang Berkeadilan, Jurnal Ilmu Hukum Amanna Gappa, Vol. 17 No. 4, 2009, p. 456

${ }^{27}$ Rustam Hasyim, "Bobato Dunia dan Bobato Akhirat Dalam Kesultanan Ternate”, Malut Pos, 2018, p. 8 
Sultanate can at least provide good governance model by prioritizing the values of local wisdom.

Bobato Dunia concept or government elite in a clear concept or structure or authority, especially in its hierarchy by establishing a Sultan occupying the highest place, then followed by the nobility. In order for the sultanate government to proceed as expected, the Sultan can be accompanied by a royal council called Bobato which deals with government and religion. In the government Bobato Dunia structure there are several royal institutions such as Gam Raha (Supreme Council of the Kingdom), Bobato Nyagimoi Se Tofkange (Legislative Institution), Fala Raha (Kolano Advisory Council or Sultan), Sabua Raha (Four Supreme Judges), and The Council of Ministers or called Bobato Madopolo consisting of Jogugu (Prime Minister), Kapita Lau (Admiral of the Navy), Soa-Sio Law (Minister of Home Affairs), Sangaji Law (Minister of Foreign Affairs), Tulilamo (State Secretary), and Sangaji (Regional Government or Governor).

All of these officials were sworn in by the Sultan and a process like this went on until now from the process of transfer of the sultanate's position which occurred. Based on the formadiyah agreement, positions in the nobility were handed down from generation to generation or called dabo se barasi from various sources which up to now remain firm in the Ternate Sultanate, such as the Marasa Oli clans, Toma Gola, Toma Ito, Jiko, Tobala and Tora Ngara. Based on existing data up to now these clans which occupy various strategic positions in the Ternate Sultanate, there are at least four strategic positions namely ${ }^{28}$ Gam Raha (Supreme Council of the Kingdom), Bobato Nyagimoi se Tufkange (Legislative Institution), Fala Raha (Kolano or Sultan Advisory Institution), Sabua Raha (Four Supreme Judges).

Whereas Bobato Akhirat or religious elite is one of the most important functions in the Ternate Sultanate which acts as the leader of the Islamic religion. How important the role of religion, especially Islam, is that in the structure of the Ternate Sultanate institution has a very strategic and santral position. But in its structure, it is still held by the Sultan as a religious leader (amir mukminin) or substitute for Rasul or tubaddilur Rasul. In carrying out the process, it still shows that it can happen because of a value system that gives legality to the position of a Sultan. In order to carry out its function and role as a cadre as expected, it can be assisted by five Imams, ${ }^{29}$ namely Imam Jiko, Imam Sangaji, Imam Moti, and Imam Jawa. Apart from the four Imams, Imam Nangsa is in charge of broadcasting religion, taking care of death ceremonies, marriages, and distributing inheritance at the district level. Whereas Imam Bangsa specifically only manages and organizes problems concerning the sultan, nobility and his family.

But based on the data in the field the values of local wisdom contained in the Ternate Sultanate cannot yet be implemented in good governance in Ternate. This shows that local government is still running with its own governance structure. If in fact these two government structures can be well combined and hopeful to realize local government that has wisdom that can be realized. Examining more deeply the various structures and institutions that exist with the existing authority both within the local government and government contained in the Sultanate of Ternate is not contradictory either in concept or theory but actually has a variety of similarities that complement each other because they all want to realize the city of Ternate which is fair and prosperous based on Pancasila and the 1945 Constitution of the Republic of Indonesia.

\footnotetext{
${ }^{28}$ Ibid.

${ }^{29}$ Ibid., p. 9
} 


\section{Conclusion}

First, the values of local wisdom in North Maluku which have relevance in supporting the administration of the government with the concept of Se Atorang local wisdom which means customs and rules, Jago loa Se Banari or honest and fair and Ceng se Cange or Popular and Humble. Local wisdom has a foundation with what is called the philosophical aspect called Philosophy: "Jo Se Ngofa Ngare", which means: "You" (ruler) and "I" (people), while in the sociological aspect called Balo Kesu Sean canoeing and normative aspects. These values provide important lessons for the community so that, thus, governance is not only in the context of formal values that apply such as the value of unity, courtesy, ethics and procedures for social interaction. but also adopting the value of local wisdom, then these two values synergize in governance as expected in a social life. Therefore, there needs to be political will from the local government to encourage various regulations, especially local regulations and various policies that are made must reflect as well as animate the various values of local wisdom because it becomes a social capital that is not only desirable from the people of North Maluku but has become the hope and desire of Indonesian society in general. Second, Understanding the values of the local wisdom of the Ternate Sultanate with the concept of Bobato Dunia and Bobato Akhirat shows that both of these philosophies contain very philosophical meanings in the relation of local wisdom values in the management of local government with the concept of power sharing which governs the problems of government or Bobatu Dunia and there are regulating religious problems Bobato Akhirat. Both of these concepts are expected to synergize in the management of local government in the Ternate. Bobato Dunia concept or government elite in a clear concept or structure or authority, especially in its hierarchy by establishing a Sultan occupying the highest place, then followed by the nobility. In order for the sultanate's government to work as expected, the Sultan could be accompanied by a royal council called Bobato which deals with government and religion, which is also assisted by several royal institutions. Therefore, the values of the local wisdom must be able to synergize with the institutional structure established in the regional government because it is a living law that has not been used as a foundation in the administration of regional government, but local wisdom from the normative aspect is guaranteed in the 1945 Constitution of the Republic of Indonesia and other laws and regulations.

\section{References}

[1] A. Mappadjantji Amien, Kemandirian Lokal-Konsepsi Pembangunan, Organisasi, dan Pendidikan dari Perspektif Sains Baru, Jakarta: PT Gramedia Pustaka Utama, 2005.

[2] Abdul Hamid Hasan, Aroma Sejarah dan Budaya Ternate, Jakarta: Antara Pustaka Utama, 2001.

[3] Aminuddin, 2013, Menjaga Linkungan Dengan Kearifan lokal, Titian Ilmu, Jakarta.

[4] Amrah Muslimin, Aspek-aspek Hukum Otonomi Daerah, Bandung: Alumni, 1978.

[5] An annual governance assessment by the Partnership Institution, accessed at "http://www.kemitraan.or.id/govindex/ dated October 20, 2015

[6] Armada Riyatno, et.al., Kearifan Lokal-Pancasila Butir-Butir Filsafat Keindonesian, Yogyakarta: PT Kanisius, 2015.

[7] Benyamin Hoessin, Kebijakan Desentralisasi, Jurnal Administrasi Negara, Vol. I, No. 02, March 2002.

[8] Dadang Solihin, Kamus Istilah Otonomi Daerah, Jakarta: Lembaga Pemberdayaan Ekonomi kerakyatan, 2001. 
[9] Law of the Republic of Indonesia Number 32 Year 2004 on Regional Government, Jakarta: Indonesia Legal Centre Publishing, 2008.

[10] Law of the Republic of Indonesia Number 32 Year 2009 on Environmental Protection and Management, State Gazette of the Republic of Indonesia Year 2009 Number 140.

[11] Law of the Republic of Indonesia Number 23 Year 2014 concerning Regional Government, State Gazette of the Republic of Indonesia in 2014 Number 244.

[12] M. Adnan Amal, 2010, Kepulauan Remah-Rempah, Perjalanan Sejarah Maluku Utara 1250-1950, KPG, Jakarta.

[13] M. Laica Marzuki, Makalah, Otonomi Daerah dalam Perspektif Indonesia Baru, Ujung Pandang: 29 September 1999.

[14] M. Ryaas Rasyid, Otonomi Atau federalisme, Jakarta: Pustaka Sinar Harapan, 2000.

[15] Peter Mahmud Marzuki, Penelitian Hukum, Jakarta: Kencana Prenada Media Group, 2010.

[16] R. Wiyono, Garis Besar Pembahasan dan Komentar UUD 1945, Bandung: Alumni, 1982.

[17] Rahmatullah H. Sahil, Relevansi Kearifan Lokal Provinsi Maluku Utara dalam Penyelenggaraan Pemerintahan Daerah, Universitas Hasanuddin (Thesis for Master Degree), 2015.

[18] Rustam Hasyim, "Bobato Dunia dan Bobato Akhirat Dalam Kesultanan Ternate", Malut Pos, 2018. Siswanto Sunarno, Hukum Pemerintahan daerah di Indonesia, Jakarta: Sinar Grafika 2008.

[19] Soerjono Soekanto and Sri Mamudji, Penelitian Hukum Normatif, Jakarta: Rajawali Pers, 2011.

[20] Syamsul Bachrie, Merekonstruksi Paradikma Membangun Supermasi Hukum yang Berkeadilan, Jurnal Ilmu Hukum Amanna Gappa, Vol. 17 No. 4, 2009. 